\title{
Future waste treatment and energy systems - examples of joint scenarios
}

\author{
Münster, Marie; Finnveden, G.; Wenzel, H.
}

Published in:

Waste Management

Link to article, DOI:

10.1016/j.wasman.2013.07.013

Publication date:

2013

Document Version

Peer reviewed version

Link back to DTU Orbit

Citation (APA):

Münster, M., Finnveden, G., \& Wenzel, H. (2013). Future waste treatment and energy systems - examples of joint scenarios. Waste Management, 33(11), 2457-2464. https://doi.org/10.1016/j.wasman.2013.07.013

\section{General rights}

Copyright and moral rights for the publications made accessible in the public portal are retained by the authors and/or other copyright owners and it is a condition of accessing publications that users recognise and abide by the legal requirements associated with these rights.

- Users may download and print one copy of any publication from the public portal for the purpose of private study or research.

- You may not further distribute the material or use it for any profit-making activity or commercial gain

- You may freely distribute the URL identifying the publication in the public portal

If you believe that this document breaches copyright please contact us providing details, and we will remove access to the work immediately and investigate your claim. 


\title{
FUTURE WASTE TREATMENT AND ENERGY SYSTEMS - EXAMPLES OF JOINT SCENARIOS
}

\author{
M. MÜNSTER*, G. FINNVEDEN** AND H. WENZEL ${ }^{\circ}$ \\ *System Analysis Division, DTU Management Engineering, Technical University \\ of Denmark, Frederiksborgvej 399, 4000 Roskilde, Denmark \\ **KTH Royal Institute of Technology, School of Architecture and the Built \\ Environment, Department of Planning and Environment, Division of \\ Environmental Strategies Research - fms, 10044 Stockholm, Sweden \\ 'Institute of Chemical Engineering, Biotechnology and Environmental Technology, \\ University of Southern Denmark, Niels Bohrs Allé 1, 5230 Odense M, Denmark
}

\begin{abstract}
Development and use of scenarios for large interdisciplinary projects is a complicated task. This article provides practical examples of how it has been carried out in two projects addressing waste management and energy issues respectively. Based on experiences from the two projects, recommendations are made for an approach concerning development of scenarios in projects dealing with both waste management and energy issues. Recommendations are given to develop and use overall scenarios for the project and leave room for sub-scenarios in parts of the project. Combining different types of scenarios is recommended, too, in order to adapt to the methods and tools of different disciplines, such as developing predictive scenarios with general equilibrium tools and analysing explorative scenarios with energy system analysis tools. Furthermore, as marginals identified in differing future background systems determine the outcomes of consequential life cycle assessments (LCA), it is considered advisable to develop and use explorative external scenarios based on possible marginals as a framework for consequential LCAs. This approach is illustrated using an on-going Danish research project.
\end{abstract}

\section{INTRODUCTION}

The waste and energy sectors may become increasingly interlinked in the future with the augmented pressure on other energy sources. To avoid sub-optimization between the two sectors it is necessary to ensure that a combined holistic planning will take place ensuring optimal utilization of waste fractions - either for recycling or for energy. As the energy sector development influences the waste sector significantly, it becomes important to understand the energy sector development as a framework condition for the waste sector and develop scenarios reflecting this.

Developing future scenarios for one sector, such as the waste sector, is a complicated task. The task becomes even more complicated when an effort is made to develop interdisciplinary 
scenarios, such as scenarios taking both the waste sector and the energy sector into account. Three issues have to be dealt with: a. The factors which might affect the future of the sectors, b. the type of tools used for analysing future developments and c. the target groups addressed.

When developing long term strategies for waste management, the norm has been to focus on factors affecting only the waste treatment sector, such as regulation and taxation/ support mechanisms. Since use of waste as an energy source will play an increasingly significant role, the energy system must, however, also be considered when scenarios for waste management are developed. Examples of relevant factors could be the expected prices for energy, the political goals for shares of renewable energy etc.

Several articles deal with the typology of scenarios in question (Börjeson et al. 2006, Höjer et al. 2008, Nielsen and Karlsson 2007) and some also contain recommendations for developing scenarios (Björk and Börjesson 1998). However, few analyse real cases where scenarios have been used in complex interdisciplinary research projects. In this article different types and uses of scenarios are first presented, then two cases of use of scenarios are analysed using two large interdisciplinary research projects as examples; one focusing on energy (CEESA) and one on waste management (TOSUWAMA). The main challenges and benefits regarding use of common scenarios for these two cases are presented. The aim is not to summarise the overall results of these two large projects, but to learn from their use of scenarios. Based on experiences from the two projects, recommendations are made for a research project, which will integrate energy system analysis with analysis of waste management (TOPWASTE).

\section{SCENARIOS}

Scenarios are normally used to assist decision makers in making strategic decisions about an uncertain future for a long term perspective. Some of the main benefits of using scenarios in large interdisciplinary research projects may be (Björk and Börjesson 1998):

- Creation of a common mental platform

- Collaboration towards the same goals

- Communicating results to a broader audience

Another important benefit is:

- Revealing how results depend on assumptions of future developments in both background systems and foreground systems

Scenarios can be divided into different types. Based on Börjeson et al (2006), we distinguish between Predictive, Explorative (external \& strategic) and Normative (preserving \& transforming), based on the type of questions they attempt to answer. Predictive scenarios answer the question "What will happen?" Although it often happens that only one scenario is used, several predictive "What if-scenarios" can be used, for example taking into account specific possible developments. Explorative scenarios answer the question "What can happen?" as well as "What can happen if...?" One type of Explorative scenario is the External scenario which focuses on factors that are external to the decision-maker, factors that the decision-maker has no, or only limited control over. Normative scenarios aim at answering the question "How can a certain target be reached?” Back casting scenarios are examples of normative scenarios.

The difference between Predictive and Explorative scenarios is not always clear-cut, but lies in the ambition of the scenario builder. Provided the aim is finding the answer to what will happen, the means will be to make predictions and thus to construct predictive scenarios. If the 
aim is finding the answer to what may happen, including what/if scenarios, different possible futures must be envisioned and explorative scenarios must be constructed. Explorative scenarios will normally be more useful when long-term considerations are made and the uncertainties about the future developments are larger. If the current trends are unreliable in the long run, there may be a case for explorative, rather than predictive scenarios.

External scenarios may be useful for decision-makers in cases of strategic policy scenarios, where possible policies are evaluated in possible external scenarios. Several criteria may be employed in explorative scenarios (c.f. Börjeson et al, 2006). They would have to be plausible; if considered completely unrealistic they are irrelevant. At the same time they should be challenging. If all they do is describe business as usual, they are more or less similar to predictive scenarios. They should be clearly different so that users of the scenarios get an indication of the possible outcomes. Finally, the scenarios should be internally consistent.

Different types of scenarios may be combined with different types of tools for systems analysis (e.g. Höjer et al, 2008). When using tools for energy systems analysis or tools for environmental systems analysis (like Life Cycle Assessment) external factors have to be assumed or calculated by another tool. These factors can e.g. be costs of different fuels - in the case of energy systems analysis - or affected energy - in the case of LCA. If the tools are used to assess future impacts, future scenarios for these external factors will be necessary. These future scenarios may be predictive or explorative, depending on the perceived uncertainty of the future developments. Normative scenarios may also be used as external scenarios. They would then answer the question: "What may happen if a certain target is achieved?"

\section{SCENARIOS IN WASTE MANAGEMENT PROJECT}

The Swedish research program “Towards Sustainable Waste Management” (sometimes abbreviated TOSUWAMA) which ran from 2007 to 2013, has involved approximately ten different research institutes with backgrounds in environmental engineering, environmental systems analysis, environmental economics, psychology and ethnology (www.hallbaravfallshantering.se). One of the aims of the program has been to develop and evaluate policy instruments for a more sustainable waste management ( Finnveden et al, 2012 and 2013). In order to carry that out, and ensuring a joint analysis using different methodological approaches, scenarios of future waste management systems have been developed after which impacts of different policy instruments in these future scenarios towards 2030 have been assessed.

The possible future impacts of new policy instruments have been assessed using both quantitative and qualitative methods. The quantitative methods include three different types of models: a macro-economic general equilibrium model (EMEC), a cost-minimising model for the Swedish waste management system (Natwaste) and an LCA model of the Swedish waste management system (SWEA) (Finnveden et al, 2013). Qualitative assessments include evaluations based on psychological and ethnological perspectives (Andersson et al, 2011). The policy instruments included economic, regulatory and informative tools addressing all parts of the waste hierarchy, i.e. waste prevention, reuse, recycling, incineration and landfilling of waste.

The different assessments require different types of information about future external factors. Hence, future scenarios including these external factors were necessary. It was decided to develop external scenarios that could be used by all sub-projects in the program in order to harmonise assumptions and facilitate data transfer between models and comparisons of results. 
The choice was made to develop external, explorative scenarios rather than predictive scenarios because a longer time perspective was of interest (until 2030) and based on experience, the results may depend on uncertain external factors. Another aim of using the scenarios was to have a structured way of handling uncertainties and the ability to analyse whether the results regarding impacts of different policy instruments would be sensitive to different possible futures.

The scenarios were developed in a process with several steps (Dreborg and Tyskeng, 2008). A number of interviews were made with participants in the research program and stakeholders. Scenarios from related projects were also studied. The aim of this work was to identify aspects or dimensions which are important for the study and have been found to be uncertain. Based on this information, preliminary scenarios were developed and discussed in a workshop with participants of the research program. The scenarios were then further processed by the scenario team in dialogue with participants of the sub-projects which made up the overall research program.

The scenarios developed include four explorative and one reference scenario, which is largely based on different "long-term projections", developed and used by the Swedish government and governmental agencies. The four explorative scenarios were developed based on two dimensions, one describing the level of globalization and one describing values of the Swedish society. These scenarios are briefly described in Fig 1 and below.

Global sustainability: The globalization continues including increased free trade and constantly changing division of labour. In this scenario there is also an increasing level of global responsibility and governance of common problems such as climate change and use of natural resources.

Global markets: As in scenario 1, the globalization continues. The overall goal is economic growth where internationalization and migration of workforce are some of the means. The political interactions to influence use of resources and to reduce environmental impacts are weaker. Few countries prioritize sustainability and social and ecomonic equity.

Regional markets: In this scenario the globalization is weakened and the regions of the world are more visible. To an increasing extent trade takes place within regions, and barriers are growing. It is difficult to develop agreements on a global level and the mitigation of climate change is not developing. Instead there is a focus on local environmental issues where the problems are urgent and more visible.

Regional sustainability: The present trend towards increased globalization is interrupted and a more regional pattern for trade and cooperation is emerging. The European Union is strengthened internally but global cooperation efforts are weakened. Within the EU, mobility, social and environmental sustainability are prioritized. Globally, the governance related to climate change and use of national resources is weak, but the EU tries to be a leader and move ahead.

The Reference scenario can be seen as a "business as usual scenario" and includes components of the others. 


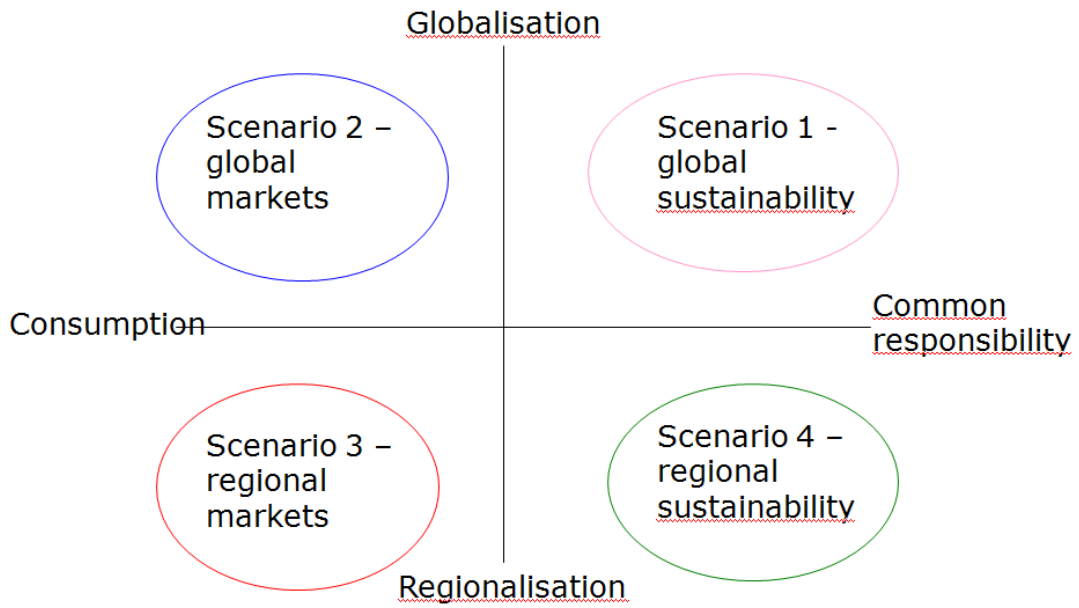

Fig 1. External explorative scenarios in TOSUWAMA (Dreborg and Tyskeng, 2008).

The scenarios included a written description, a story-line as well as tables of more specific aspects that were needed for different projects in the program. These included both qualitative and quantitative aspects. Examples of some key parameters are given in Table 1. More details are available in Dreborg and Tyskeng (2008).

As can be seen in Table 1, the Reference scenario developed by the Swedish government is used as a starting point. The assumption is that economic growth in Sweden will develop in the global sustainability scenario like in the reference scenario - somewhat faster in the global market because of its focus on economic growth, and somewhat slower in the regional scenarios. The price of raw materials is assumed to develop faster in the market scenarios but in line with the reference scenario in the sustainability scenarios due to the introduction of policies to support a more sustainable use of resources. The price of Carbon emission credits in Europe is assumed to develop differently in the different scenarios in relation to the focus on climate change mitigation in the different scenarios.

Table 1. Examples of aspects described in the different scenarios. LU 2008 is a scenario developed by the Swedish government and often used as an "official reference scenario” (Dreborg and Tyskeng, 2008).

\begin{tabular}{|c|c|c|c|c|c|}
\hline & $\begin{array}{l}\text { Refe- } \\
\text { rence }\end{array}$ & $\begin{array}{c}\text { Global } \\
\text { Sustainability }\end{array}$ & $\begin{array}{l}\text { Global } \\
\text { Market }\end{array}$ & $\begin{array}{l}\text { Regional } \\
\text { Market }\end{array}$ & $\begin{array}{c}\text { Regional } \\
\text { Sustainability }\end{array}$ \\
\hline $\begin{array}{l}\text { Econ. } \\
\text { growth in } \\
\text { Sweden }\end{array}$ & $\begin{array}{c}\text { LU } \\
2008\end{array}$ & LU 2008 & $\begin{array}{c}1.26 * \mathrm{LU} \\
2008\end{array}$ & $\begin{array}{l}0.88 * \mathrm{LU} \\
2008\end{array}$ & $0.88 *$ LU 2008 \\
\hline $\begin{array}{l}\text { Price of } \\
\text { raw mat. }\end{array}$ & $\begin{array}{c}\text { LU } \\
2008\end{array}$ & LU 2008 & $\begin{array}{c}2.5 * \\
\text { LU } 2008\end{array}$ & 2 *LU 2008 & LU 2008 \\
\hline $\begin{array}{l}\text { Price of C } \\
\text { emiss. } \\
\text { credits }\end{array}$ & $\begin{array}{c}\mathrm{LU} \\
2008\end{array}$ & $\begin{array}{c}2 * \\
\text { LU } 2008\end{array}$ & $\begin{array}{c}0.75 * \\
\text { LU } 2008\end{array}$ & LU 2008 & $\begin{array}{c}1.5 * \\
\text { LU } 2008\end{array}$ \\
\hline $\begin{array}{l}\text { Env. } \\
\text { policy }\end{array}$ & & $\begin{array}{l}\text { Climate change but } \\
\text { also local and reg. }\end{array}$ & $\begin{array}{l}\text { Focus on } \\
\text { local and }\end{array}$ & $\begin{array}{l}\text { Focus on } \\
\text { local and }\end{array}$ & $\begin{array}{l}\text { Reg. and local } \\
\text { but also global }\end{array}$ \\
\hline
\end{tabular}


After the scenario report (Dreborg and Tyskeng, 2008) was published, the scenarios were further discussed in program conferences where the researchers met in order to discuss the need for possible additions to the scenarios. For example, the LCA models needed further information about the energy and transportation systems which therefore had to be developed (Arushanyan et al, 2013).

\subsection{Results}

Based on the external scenarios (Dreborg and Tyskeng, 2008) and the EMEC model, scenarios for waste generation in 2030 could be developed (Östblom et al, 2010). In all scenarios the waste generation increased but quite differently, ranging from a limited increase of approx. $10 \%$ to approx. $100 \%$. This difference was partly related to differences in economic growth, but other aspects such as technological development and changes in waste intensities were important, too. The latter would be influenced by policies aiming at waste prevention in line with the waste hierarchy of the European Union. A doubling of waste until 2030 would seem to be in conflict with current aims, suggesting the need for increased efforts in the area of waste prevention.

Based on the scenarios, including waste generation, a cost-efficient waste management system could be calculated for the different scenarios. However, the differences in the preferred waste treatments between the scenarios were limited in the Natwaste optimising model (Ljunggren Söderman, 2013). This also meant that the impacts of the different policy instruments were rather similar in the different scenarios, suggesting that conclusions concerning policy instruments are fairly robust in terms of future developments (Finnveden et al, 2013). The use of scenarios therefore made it possible to be more confident in the conclusions.

In the development and use of the scenarios, several tools and methods were used. The first step was mainly taken using qualitative methods such as interviews, workshops and analysis of previously published studies (Dreborg and Tyskeng, 2008). The scenarios were then analysed and at the same type further developed using different tools. Firstly a general equilibrium model was used to generate information about the waste amounts which developed the scenarios (Östblom et al, 2010). The next step was to employ an optimising tool for the waste management system which again was used to analyse the scenarios but also to develop them in terms of describing economically optimal waste management treatments systems for the different scenarios (Ljunggren Söderman, 2013). Finally these developed scenarios were analysed using Life Cycle Assessment (Arushanyan et al, 2013). Furthermore, qualitative assessments of acceptability of different policy instruments were performed for the different scenarios (Andersson et al, 2011). Different types of assessments and scientific disciplines were therefore involved in the development and analysis of the common scenarios.

The TOSUWAMA use of common scenarios was necessary since the different models need information about the future regarding different external factors. Since the aim was to connect the different models by using outputs from one model as inputs to another (so called softlinking), it was necessary that the same scenarios be used. This worked rather well. To our knowledge, the soft-linking between these three types of models (a General Equilibrium Model, an Optimising model and a Life Cycle Assessment model) for the waste management sector has not been used before. It is an example of the combination of tools that may be part of a more 
comprehensive Life Cycle Sustainability Assessment (Guinée et al, 2011).

During the work it became clear that the use of scenarios is quite different in the variuos scientific traditions. Whereas some of the researchers were quite used to employing explorative scenarios, others were more used to having one predictive scenario, perhaps changing one or two parameters in a sensitivity analysis. Others, especially those from the qualitative sciences, were not at all habitually working with future scenarios. As mentioned above, one of the criteria for explorative scenarios is that they should be quite different. It may well be assumed that many of the researchers in the program feel that the scenarios did not differ sufficiently. One reason for this may be that some of the researchers and other members did not feel used to working with explorative scenarios and tended to think in terms of predictions, thus making the scenarios rather similar.

One of the difficulties was to define the border between external and internal factors for the waste management system. The reason for this is that some factors may be external to some stakeholders in the waste management system, but not to others. For example, CO2-tax on different fuels is external to many of the stakeholders in the waste management system, but not to the Swedish government which is also a part of the Swedish waste management system. Values among citizens, too, are external to some stakeholders, but not to the citizens themselves. The difference between internal and external factors is not purely academic, since it may become difficult to analyse impacts of policy measures in the different scenarios if they are already included in the scenarios.

Another difficulty was that the subprojects needed to define some parameters not already defined in the external scenarios. One example was the energy mixes for the LCA subproject. However, it was not apparent how the energy mixes could be linked to the external scenarios, making them less relevant in these aspects. Therefore the dimension included in the scenarios did not fully capture some important and uncertain aspects although this is one of the criteria for external scenarios as discussed above. The importance of the energy systems for the outcome of the LCA results is well-known (e.g. Björklund and Finnveden, 2005, WRAP, 2006) also among the LCA researchers of the project, but it did not influence the scenarios. This was possibly because the scenario team were looking for dimensions that the majority of the project participants thought were important, and the LCA researcher were a minority in the project. A key learning for future projects was hence to ensure that external scenarios include the key parameters, which we know may be decisive for the outcome of the planned analyses, such as the affected energy mix.

The use of scenarios in TOSUWAMA fulfilled its main goal to provide common data regarding external factors for the different models on an overall level. These data were necessary for joint use of the models, the internal collaboration and communication. It also provided a tool for communicating results about possible future waste amounts to the external target groups.

\section{SCENARIOS IN ENERGY PROJECT}

The Danish strategic research project "Coherent Energy and Environmental System Analysis” (CEESA) was conducted in the period 2007-2011. It was funded by the Danish Strategic Research Council as well as the participating parties. The main question was how to achieve $100 \%$ renewable energy in the Danish energy system involving the smallest degree of environmental impact - focusing on transportation, the power system and regulatory measures. The project was interdisciplinary and involved more than 20 researchers from 7 different 
university departments or research institutions in Denmark. The results include further development and integration of existing tools and methodologies into coherent energy and environmental analysis tools as well as analyses of the design and implementation of future renewable energy systems. (Lund et al. 2011)

The project applied scenarios in order to ensure coherent and coordinated analysis of energy systems and environmental impacts as well as policy recommendations applying both quantitative and qualitative methods. The purpose of using scenarios was also to ensure common results and facilitate communication of results.

The scenarios in CEESA are based on the "Wind" and "Bio" scenarios originally developed in a project of the Danish Engineering Association (Lund and Mathiesen 2006). These scenarios were used as a starting point in the CEESA projects, where the scenarios were updated and further developed e.g. regarding transport. The first step was to discuss the scenarios. There it was argued that high and low energy consumption should also be parameters spanning out the scope of the scenarios, but instead this aspect was investigated with a sensitivity analysis in the end. Along the way, further research questions arose and it became necessary to analyse sub scenarios regarding transport, agriculture and life cycle assessment. All scenarios were normative, in the sense that they analyse a future with 100\% renewable energy in Denmark. They were, however, also internal explorative scenarios focusing particularly on different energy technologies as illustrated in Table 2. Forecasting was employed to establish a predictive Business As Usual (BAU) reference scenario. Energy System Analysis was performed to analyse the different energy technologies and finally consequential LCA was applied using the same marginals for different scenarios and performing sensitivity analyses for other marginals. From the beginning of the project it was agreed to have internal explorative/ normative scenarios. During the project it was discussed how, in the results, to illustrate the significance of different assumptions regarding development in the surrounding world. In the end, however, not much emphasis was given to the external background systems apart from differing assumptions regarding technological development. The final scenarios are illustrated in Table 2 and explained below, based on (Lund et al. 2011).

CEESA - 2050 Conservative: The conservative scenario was created using mostly known technologies and technologies which are available today. This scenario assumes that the current market can develop and improve existing technologies. The costs of undeveloped renewable energy technologies are high and little effort is made to push the technological development of new renewable energy technologies in Denmark or on a global level. The scenario does however assume further technological developments of electric cars, hybrid vehicles, and bioDME/methanol production technology (including biomass gasification technology).

CEESA - 2050 Ideal: In the ideal scenario, technologies which are still in the development phase are included on a larger scale. The costs of undeveloped renewable energy technologies are low, due to significant efforts to both develop, demonstrate and create markets for new technologies. For example, the ideal scenario assumes that fuel cells are available for power plants, and biomass conversion technologies (such as gasification) are available for most biomass types and on different scales. Co-electrolysis is also developed and the transport sector moves further ontowards electrification compared to the conservative scenario.

CEESA - 2050 Recommended: This scenario is a "realistic and recommendable" scenario based on a balanced assessment of realistic and achievable technology improvements. Here, less co-electrolysis is used and a balance is implemented between bio-DME/methanol and syn$\mathrm{DME} /$ methanol in the transport sector. 
Table 2. Examples of aspects described in the different CEESA scenarios (Lund et al. 2011)

\begin{tabular}{|c|c|c|c|}
\hline CEESA-2050 & $\begin{array}{l}\text { Conservative } \\
\text { (Bio) }\end{array}$ & Ideal (Wind) & Recommended \\
\hline \multicolumn{4}{|c|}{ Renewable energy and conversion technologies } \\
\hline Wind power & $12,100 \mathrm{MW}$ & $16,340 \mathrm{MW}$ & $14,150 \mathrm{MW}$ \\
\hline Photo Voltaic & - & 7,500 MW & 5,000 MW \\
\hline Wave Power & & $1,000 \mathrm{MW}$ & $300 \mathrm{MW}$ \\
\hline $\begin{array}{l}\text { Small Combined Heat } \\
\text { and Power Plants }\end{array}$ & Engines & $\begin{array}{l}\text { Small Fuel } \\
\text { Cell CHP }\end{array}$ & $\begin{array}{l}\text { Engines / Fuel cells } \\
\text { Gas turbine }\end{array}$ \\
\hline $\begin{array}{l}\text { Large Combined Heat } \\
\text { and Power Plants and } \\
\text { Power Plants }\end{array}$ & $\begin{array}{c}\text { Gas turbine } \\
\text { Combined Cycle/ } \\
\text { Combustion } \\
\end{array}$ & $\begin{array}{c}\text { Large Fuel } \\
\text { Cell Combined } \\
\text { Cycle CHP/PP }\end{array}$ & $\begin{array}{c}\text { Combined Cycle / } \\
\text { Large Fuel Cell } \\
\text { Combined Cycle CHP/PP }\end{array}$ \\
\hline $\begin{array}{l}\text { Gasification for } \\
\text { electricity and power } \\
\text { production }\end{array}$ & Yes partly & Yes & Yes \\
\hline \multicolumn{4}{|c|}{ Transport technologies } \\
\hline Direct electricity & $87 \%$ & $23 \%$ & $22 \%$ \\
\hline Bio-DME/Methanol & $13 \%$ & $0 \%$ & $44 \%$ \\
\hline Syn-DME/Methanol & - & $77 \%$ & $34 \%$ \\
\hline $\begin{array}{l}\text { Bio-DME/Methanol } \\
\text { plants }\end{array}$ & Yes & No & Yes \\
\hline $\begin{array}{l}\text { Electrolysers for Bio- } \\
\text { DME/Methanol plants }\end{array}$ & Yes & No & Yes \\
\hline $\begin{array}{l}\text { Co-Electrolysers for Syn- } \\
\text { DME/Methanol plants }\end{array}$ & No & Yes & Yes \\
\hline
\end{tabular}

The Conservative and Ideal scenarios are used to illustrate that different technological developments will have different effects on the extent of the use of biomass resources, as well as the requirements for flexibility and smart energy system solutions. In all scenarios, energy savings and direct electricity consumption are given a high priority.

In the Conservative technology scenario, a 100\% renewable energy system is possible with a total biomass consumption of 331 PJ. The Ideal technology scenario can decrease this consumption to 206 PJ of biomass. In the CEESA 2050 Recommendable scenario, the biomass consumption is $237 \mathrm{PJ}$ and thus $30 \mathrm{PJ}$ higher than in the Ideal and $96 \mathrm{PJ}$ lower than in the Conservative scenario.

\subsection{Results}

The main tools applied in the project were system tools such as energy system analysis using simulation/rule based optimization, consequential life cycle assessment, general equilibrium model and tools for assessing biomass potentials. The tools were used to make quantitative assessment of the overall scenarios or sub scenarios defined during the course of the project. Least attention was given to the scenarios in the part of the project which carried out more qualitative analysis of regulatory frameworks. The results of the project show that a $100 \%$ renewable energy system in Denmark is feasible. Energy storage and the transport sector are the 
major challenges, however, in particular when taking limited biomass resources into account. Storing energy as heat and gas might be a solution. Likewise, despite the energy losses entailed, wind energy might be used for electrolysis to produce storable transportation fuels such as methanol.

The overall purposes - of using scenarios to align the interdisciplinary work and achieving common results which were easy to communicate - were achieved to some extent. Although different sub scenarios were investigated by the disciplinary teams, they all contributed to the overall question of how to achieve 100\% renewable energy in the Danish energy system with the least environmental impact focusing on the "Wind" and "Bio" scenarios.

The main challenges in the project concerned ensuring that the different disciplines all contributed to a common context and keeping momentum in the large geographically divided group - remembering status and agreements from one meeting to the next. One of the main benefits of the broadly defined scope of the project was the opportunity for networking within the project and cooperation on analysis of issues raised in society in the course of the project.

\section{SUMMARY AND DISCUSSION OF SCENARIO EXPERIENCES}

In both projects existing scenarios were taken as a starting point and different types of scenarios were combined to a large extent, making it difficult to make clear distinctions between the types of scenarios used (See Table 3). Different tools and different types of scenarios were, however, applied in the two projects. In the TOSUWAMA project, external explorative mediumterm scenarios were analysed and also further developed using a general equilibrium model and an optimization tool and finally analysed using life cycle assessment and qualitative assessments. These tools were used to analyse different policy instruments aiming at for example, waste prevention or increased recycling. In CEESA, normative and internal explorative long-term scenarios were combined, primarily with system and simulation tools. Höjer et al. (2008) describe optimising modelling as relevant for developing all types of scenarios apart from normative transforming scenarios, whereas explanatory modelling, which simulation tools may be used for, is not deemed relevant for development of neither preserving nor transforming normative scenarios. This is not completely in line with the findings in this article, where simulation tools were used for analysis of normative internal explorative scenarios, and optimising tools were used only for analysis of external explorative scenarios.

Table 3. Scenario types and tools applied in TOSUWAMA and CEESA

TOSUWAMA

CEESA

\begin{tabular}{lcc}
\hline $\begin{array}{l}\text { Predic- } \\
\text { tive }\end{array}$ & $\begin{array}{c}\text { BAU reference scenario } \\
\text { Forecasting/ general equilibrium } \\
\text { tools }\end{array}$ & $\begin{array}{c}\text { BAU reference scenario } \\
\text { Forecasting/ general equilibrium tools }\end{array}$ \\
\hline $\begin{array}{l}\text { Explora- } \\
\text { tive }\end{array}$ & $\begin{array}{c}\text { External scenarios } \\
\text { (Globalisation/regionalisation \& } \\
\text { market/sustainability) } \\
\text { General equilibrium models, } \\
\text { Optimisation tools }\end{array}$ & $\begin{array}{c}\text { Strategic, internal scenarios (energy } \\
\text { technology, energy consumption, } \\
\text { agriculture) }\end{array}$ \\
$\begin{array}{l}\text { Norma- } \\
\text { tive }\end{array}$ & & System/ simulation tools \\
\hline & & 100\% RE in DK (transforming scenario) \\
& & System/ simulation tools \\
\hline
\end{tabular}


Experience from the two projects show that although one may initially have a clear idea of which types of scenarios to use in a project, a need may arise to integrate further sub scenarios, due to new realizations and questions arising along the way, and this may lead to important findings. In the end - instead of all disciplinary teams cooperating on analysis of a common set of scenarios one team may end up analysing the overall scenarios. The other disciplinary teams may then analyse different sub scenarios, thus contributing to improvement of analysis of overall scenarios and complementing with analyses of questions which have appeared along the way.

Both projects experienced a challenge in developing a common language for the various disciplines represented and in both cases it was most difficult for the more qualitative teams to use scenarios as a platform for establishing a common framework for analysis. Furthermore, both projects experienced a challenge in terms of using scenarios to analyse future possible environmental impacts when applying LCAs. This was also found to be an important issue in Höjer et al. (2008), where the need for further research in this field is also expressed.

In conclusion, the main purpose of using common overall scenarios was achieved in the projects. Hence a common framework for interdisciplinary discussions in both projects was provided, thereby ensuring development of a common language as well as joint understanding of main issues. Similarly, the common scenarios ensured use of the same assumptions and thereby soft-linking and exchange of data among tools. Joint and easy communication of results proved more complicated, as did ensuring direct cooperation among teams with different disciplinary backgrounds. On the whole, the experiences from the projects illustrate the need of a common overall goal - as well as the need for flexibility in terms of providing space for analysis of other issues arising along the course of the project.

Finally, experiences from both projects underline the need to ensure, that the scenarios reflect important, uncertain and quite different assumptions, not only within the internal foreground systems but also with regard to the external background systems, as results may depend heavily on these.

\section{A JOINT WASTE AND ENERGY SCENARIO APPROACH}

In the Danish research project "The Optimal Treatment of Waste" (TOPWASTE) the waste management and energy perspectives are integrated. Future scenarios are developed to take into account factors which affect both waste treatment and the energy system significantly, and which are very uncertain. Based on experiences from the two projects, this section outlines an approach for scenario use in a joint waste and energy project. The project should:

- Develop common future scenarios to create a common terminology and framework for discussions and cooperation

- Base analyses on a few common overall scenarios and allow space for more detailed analysis of differing sub-scenarios along the way

- Use the same overall assumptions to facilitate soft-linking of tools and exchange of data as well as joint communication of results

- Take existing well-known scenarios as the starting point

- Ensure that the scenarios reflect important, uncertain and quite different assumptions which make it possible to illustrate how results depend on assumptions of future developments in both background systems and foreground systems 
In the Danish waste management system, hardly any landfilling of organic materials takes place, and the main municipal waste management pathways are material recovery and incineration with energy recovery. In such a system, it is well documented that not only are the emissions from the waste treatment technologies themselves of significance but also the way in which energy and materials are recovered, thereby interacting with surrounding systems in the replacement of other sources of energy, materials, fertilizers, etc. (cf. e.g. WRAP, 2006, Tyskeng and Finnveden, 2010). When striving to optimise waste management, a key question is therefore, how best to interact with adjoining production systems for energy, materials and chemicals.

Further, in the strategic development of the waste sector, any LCA or other system analysis is used to support strategic decisions with long term implications. The framework of background systems assumed in the analyses, therefore, is supposed to represent the future development and state of these systems, and this in turn calls for explorative scenarios in which potential developments are identified and represented.

The TOPWASTE research project aims at developing knowledge and analyses to support strategic decisions, the time perspective is the long term, i.e. towards 2050, and the scenario development, thus, mainly explorative. Further, the TOPWASTE program has the specific aim of looking at the waste sector optimization within the frames of a renewable energy system in Denmark i.e. a normative scenario. Thus rendering a specific part of the scenarios setting predefined to some extent, at least qualitatively, even though alternative fossil fuel based systems will also be included for comparison.

An overall research question of TOPWASTE is:

- What is the role of waste management in the renewable energy system in Denmark and how is it environmentally and economically optimised within the frames of such a system?

- and further:

- In which ways is waste management optimisation against a renewable energy system different from optimising waste management against business-as-usual fossil fuel based systems?

It is, thus, the aim of TOPWASTE to identify pathways for strategic development of Danish waste management specifically in order to support renewable energy systems in the technically, environmentally and economically best way, but also to find out if the identified optimal development pathways are robust to changes in and uncertainties of future framework conditions.

Many studies have made an effort to analyse the implications of recovering energy from waste in the form of electricity and heat, including replacement of alternative provisions of today's electricity and heat supplies (cf. Astrup et el, 2009). Likewise, many studies have looked at implications of material recovery and replacement of virgin material productions of cardboard, paper, glass, plastics, etc. (Björklund and Finnveden, 2005). In all such cases, these models of system expansion, when including the avoided supplies, are important to the results and conclusions of the study. Within the consequential LCA approach (cf. e.g. Ekvall and Weidema, 2004), this dependency on assumptions largely boils down to which marginal supplies have been assumed.

Few studies, however, have looked specifically into analysing waste management against fully renewable energy systems. In its effort to do this, TOPWASTE aims to break the research questions down into further questions including the task of identifying the marginal supplies of all essential, affected systems including the energy and transport systems as well as the agricultural systems: 
The energy and transport systems: In a society with no fossil fuels, a key framework condition for the waste sector is the energy system itself, i.e. electricity and heat supplies and fuels for transport. The renewable energy system is characterized by fluctuating supplies and an increased task in balancing supply and demand of electricity (Lund et al. 2011). A main challenge of the renewable energy system is, thus, to provide electricity when 'the wind is not blowing'. Where today's energy recovery from waste works on a continuous basis providing base load electricity and district heating, waste energy recovery in the renewable energy system will be likely to run more intermittently and serve as electricity provider when the wind is not blowing. This can be facilitated through storage of certain waste fractions or waste derived fuels. In the renewable energy system, there is likely to be a huge difference between the inflexible base load electricity marginal and the flexible peak electricity marginal leading to very different environmental (and economic) performance when base load supply is changed to peak load. Furthermore, some renewable energy scenarios comprise a large degree of heat pumps for wind power based district heating, and this could potentially eliminate a large part of the demand for waste heat recovery.

Agricultural systems: There is a general global development towards increased demand for agricultural land. At present it is driven mainly by development towards more meat on the menu, but with an increasing degree of renewable energy, it is expected to be increasingly driven by a demand for biomass for energy (Wenzel, 2010). The implication of this is that increased global demand for energy crops implies new land cultivation with high environmental consequences on global warming and biodiversity. This, in turn, implies high environmental benefits of any material and bio-carbon recovery from waste streams that can replace demands for energy crops.

As part of the renewable energy strategy, Denmark, like many other countries, has high targets for manure biogas in agriculture. A key problem is, however, that manure is too diluted for economically attractive biogas production. Moreover, the availability of co-substrates for biogas is limited, and in many places, like e.g. Germany, energy crops (grass and maize) are used as co-substrates. High manure biogas targets, therefore, make up an opportunity for the waste sector to supply bio-waste co-substrates for the agricultural biogas sector, and the avoided marginal may well be an energy crop. Compared to the situation hitherto, this implies a large change in environmental and economic benefit of separating bio-waste streams. As the environmental and economic performance of waste management is so strongly dependent on framework conditions, it does not make sense to talk about optimization without being conscious and specific about assumptions of these systems.

Marginal production technologies, defined as the technologies affected by small changes in demand or consumption, are used in consequential life cycle assessments to identify the consequences of a decision (Ekvall and Weidema, 2004). In the TOPWASTE project external background scenarios will initially be defined by possible marginals. These external factors are used to shape conceptual scenarios, which are further complemented by quantitative assumptions concerning e.g. energy prices in the various scenarios. Subsequently, different internal foreground technology scenarios focusing on waste treatment technologies are analysed within the framework of the external background scenarios as illustrated in Figure 2. Here, quite different waste treatment technology scenarios constitute the internal foreground scenarios. Each of these scenarios are analysed against different scenarios regarding the background systems. The background system scenarios are defined by assumptions regarding: a) the Danish energy and transport system (demands and production technologies), b) the Nordic energy system - as this forms part of the electricity market, and finally c) the global resource markets defined in terms of GHG emission reduction targets, resource prices and marginal production technologies 
when replacing energy demand or feedstock.

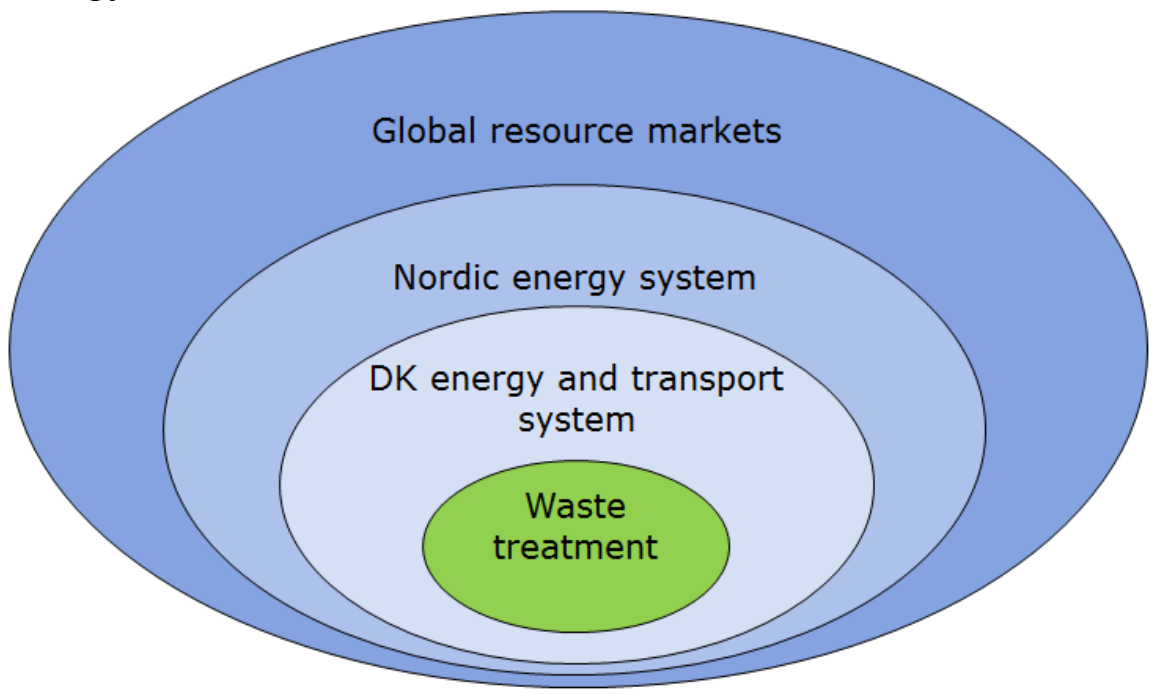

Figure 2: Waste treatment and background systems

Based on the described approach, a range of different types of scenarios will be applied in the TOPWASTE project. Table 3 illustrates connections between the type of questions asked and the scenarios and tools applied.

Table 3. Questions, scenario types and tools

Questions

Scenarios

Tools

How much waste will we Predictive scenarios (based on economic Forecasting

have? forecast scenarios)

\begin{tabular}{lcc}
\hline $\begin{array}{l}\text { What will the optimal } \\
\text { treatment of waste be? }\end{array}$ & $\begin{array}{c}\text { External explorative scenarios (affecting waste } \\
\text { and energy sectors) }\end{array}$ & Optimisation \\
\hline $\begin{array}{l}\text { What will the environmental } \\
\text { consequence be? }\end{array}$ & $\begin{array}{c}\text { Internal explorative or normative scenarios } \\
\text { (regarding waste treatment) }\end{array}$ & LCA \\
\hline $\begin{array}{l}\text { Is it possible to achieve goals } \\
\text { such as } 100 \% \text { recycling of } \\
\text { fossil based waste? }\end{array}$ & $\begin{array}{c}\text { Normative scenarios (regarding waste } \\
\text { treatment) }\end{array}$ & Simulation \\
\end{tabular}

\section{CONCLUSION}

Based on experiences from projects analysing waste management and energy systems respectively, recommendations have been made for an approach to scenario analysis of a project addressing both sectors, exemplified by the TOPWASTE project.

When using scenarios in large interdisciplinary projects it is recommended to develop and analyse common overall scenarios - but maintain flexibility to add sub scenarios analysed only by parts of the project along the way. Different projects may have different needs and using a subsidiary principle, sub-scenarios can be defined at the sub-project level. Since the amount of scenarios can easily become large - if sub-scenarios are used on top of the original scenarios, it is important to keep their number low, but still they need to reflect the important dimensions for 
the study.

Furthermore, the different disciplinary teams involved in the project may need to use different types of scenarios for their analyses. A broad flexible framework does, however, allow for the combination of different types of scenarios. As examples explorative scenarios can be based on normative scenarios, and predictive "business-as-usual"-scenarios can be used as one out of several explorative scenarios.

Some of the important challenges identified are how to perform LCA's on future scenarios and how to ensure that scenarios reflect the most important parameters on which the results depend, including assumptions of future developments in both background systems and foreground systems. In order to handle these challenges, it is recommended to use explorative external scenarios taking possible marginals as starting points to support consequential LCA, in order to understand the environmental consequences related to implementing different waste treatment technologies in different background systems.

\section{ACKNOWLEDGEMENTS}

The Authors wish to thank the other members of the TOPWASTE project for inspiration and valuable discussions. We furthermore wish to thank Prof. Henrik Lund for his input regarding the CEESA project. Comments from anonymous reviewers are also much appreciated.

Finally, we would also like to gratefully acknowledge the financial support of the Danish Strategic Research Council to the TOPWASTE project.

\section{REFERENCES}

Andersson, M., von Borgstede, C., Eriksson, O., Guath, M., Henriksson, G., Sundqvist, J.O., Åkesson, L., 2011. Hållbar avfallshantering - utvärdering av styrmedel från psykologiskt och etnologiskt perspektiv. TRITA-INFRA-FMS: 2011:5. KTH, Stockholm, Sweden.

Arushanyan, Y., Björklund, A., Eriksson, O., Finnveden, G., Ljunggren-Söderman, M., Sundqvist, J.O., Stenmarck, Å. 2013. Environmental assessment of waste policy instruments in Sweden (prel title). (in progress).

Astrup, T., Moller, J., and Fruergaard, T., 2009. Incineration and co-combustion of waste: accounting of greenhouse gases and global warming contributions, Waste Management \& Research, 27, 8, 789-799.

Björk, S. and Börjesson, M., 1998. Joint Interdisciplinary Research Programs: the Next Generation Creating a common mental platform by using scenario planning, Archives, The Pennsylvania State University CiteSeerX.

Björklund, A. and Finnveden, G. (2005): Recycling revisited - life cycle comparisons of global warming impact and total energy use of waste management strategies. Resources, Conservation and Recycling, 44, 309-317

Börjeson, L., Höjer, M., Dreborg, K.-H., Ekvall, T. and Finnveden, G., 2006. Scenario types and techniques - Towards a user's guide. Futures, 38, 723-739.

Dreborg, K.H. and Tyskeng, S., 2008. Framtida förutsättningar för en hållbar avfallshantering Övergripande omvärldsscenarier samt referensscenario. TRITA-INFRA-FMS 2008:6, Miljöstrategisk analys - fms, KTH Royal Institute of Technology, Stockholm, Sweden (In 


\section{Swedish).}

Ekvall, T. and Weidema, B. P., 2004. System boundaries and input data in consequential life cycle inventory analysis, International Journal of Life Cycle Assessment, 9, 3, 161-171.

Finnveden, G., Bisaillon, M., Noring, M., Stenmarck, Å., Sundberg, J., Sundqvist, J.O., Tyskeng, S., 2012. Developing and evaluating policy instruments for sustainable waste management. International Journal of Environment and Sustainable Development, 11, 19-31..

Finnveden, G., Ekvall, T., Arushanyan, Y., Bisaillon, M., Henriksson, G., Gunnarsson Östling, U., Ljunggren Söderman, M., Sahlin, J., Stenmarck, Å., Sundberg, J., Sundqvist, J.-O., Svenfelt., Å., Söderholm, P., Björklund, A., Eriksson, O., Forsfält, T., Guath, M., 2013. Policy Instruments towards a sustainable waste management. Sustainability, 5, 841-881.

Guinée, J., Heijungs, R., Huppes, G., Zamagni, A., Masoni, P., Buonamice, R., Ekvall, T. And Rydberg, T., 2011. Life Cycle Assessment: Past, Present and Future. Environmental Science \& Technology, 45, 90-96.

Höjer, M., Ahlroth, S., Dreborg, K.-H., Ekvall, T., Finnveden, G., Hjelm, O., Hochschorner, E., Nilsson, M., Palm, V., 2008. Scenarios in selected tools for environmental systems analysis. J Cleaner Prod., 16, 1958-1970.

Ljunggren Söderman, M., 2013. Ekonomisk analys av nya styrmedel för hanteringen av svenskt avfall, Rapport B2021, IVL.

Lund, H., Hvelplund, F., Vad Mathiesen, B., Alberg Østergaard, P., Christensen, P., Connolly, D., Schaltz, E., R. Pillay, J., Pagh Nielsen, M., Felby, C., Scott Bentsen, N., Tonini, D., Astrup, T., Meyer, N. I., Heussen, K., Morthorst, P. E., Møller Andersen, F., Münster, M., Pade Hansen, L., Wenzel, H., Hamelin, L., Munksgaard, J., Karnøe, P. and Lind, M., 2011. Coherent Energy and Environmental System Analysis. Department of Development and Planning, Aalborg University. 93 p., ISBN: 978-87-91404-15-3

Lund, H. and Mathiesen, B. V., 2006. The Danish Engineering Society's Energy Plan 2030 Technical energy system analyses, socio-economic assessment and quantification of business potential. Danish Engineering Society, Copenhagen, Denmark

Nielsen, S. K. and Karlsson, K., 2007. Energy scenarios: A review of methods, uses and suggestions for improvement. International Journal of Global Energy Issues, 27, 3, 302-322.

Tyskeng, S. and Finnveden, G. (2010): Comparing energy use and environmental impacts of recycling and incineration. Journal of Environmental Engineering, 136, 744-748

Wenzel, H., 2010. Breaking the biomass bottleneck of the fossil free society. 22-9-2010. CONCITO, Copenhagen, Denmark

WRAP, 2006. Environmental benefits of recycling. Banbury, ISBN 1-84405-263-X

Östblom, G., Ljunggren Söderman, M., Sjöström, M., 2010. Analysing future waste generation soft linking a model for waste management with a CGE-model for Sweden. Working Paper 118, Konjunkturinstitutet, Stockholm, Sweden. 